\section{In 250 Children, the Transmission of Allergy and Asthma is Chief Genetic, If these Children are Asthmatic}

\section{Abstract}

There seems to be no unanimity of opinion as to the mode of transmission of allergic disease. According to some, allergy is transmitted as a simple Mendelian dominant. In direct contrast, others maintain that the findings favor a recessive mechanism. Furthermore, others suggest that the condition is inherited as a "partial dominant" disorder. An additional analysis of family studies as well as data already published, failed to support either the simple dominant or recessive theory. The dominant theory does not explain why in more than half of the pedigrees both parents are normal. The recessive theory is refuted by the existence of pedigrees in which both parents are affected, yet some of the children are normal. To put more order in this complex mess, we have decided to study the genetic risk of children with a family history (FH) of allergy, we have therefore formed this prospective study in 250 children that included: family (FH) and personal history, skin prick tests (SPTs) and specific IgE (RAST), who were admitted to the Pediatric Allergy and Immunology Division of Rome University since they were affected with respiratory allergy. We have prepared a sheet with questions and possible answers. Consequently, we have studied the $\mathrm{FH}$ of these children asking whether their parents and brothers/sisters had atopic diseases, and specifying whether such disorders were respiratory or food allergies (FA). The parents of all children gave their informed consent. We analyzed data using the X2 method. $42.3 \%$ of their parents were atopic, as well as their 20 brothers/sisters. In total, $90.2 \%$ of fathers, $84 \%$ of mothers and $65 \%$ of brothers/sisters had asthma or allergic rhinitis (AR). We add that some parents had urticaria, further there were mothers and brothers/sisters experiencing atopic dermatitis (AD), and some mothers with food allergy (FA). In 23 children from these parents most had $A D$ and respiratory allergy. In 250 children comparable for age and sex with no respiratory disorder supplied from our outpatient clinic 40 parents, 14 mothers and 26 fathers and 9 brothers/sisters had asthma or AR $(p=0.0001)$, some fathers had also urticaria and two brothers AD. A major part of respiratory allergy is not transmitted by mothers: we stress that $42.3 \%$ of parents are atopic, and $\mathrm{FH}$ of their children was positive for respiratory allergy in $82-92 \%$ of cases. Thus respiratory allergy can have an autosomal dominant mode of inheritance, but considering the other atopic diseases, the transmission can be polygenic. The impact of genetic factors in these children is stressed by the relevant quote of asthmatic brothers/sisters.

Keywords: Children; Asthma; Urticaria; Mendelian dominant

\author{
Arnaldo Cantani ${ }^{1}$ \\ Department of Pediatrics, Division \\ of Allergy and Immunology, Roma \\ University La Sapienza, Italy
}

Corresponding author: Arnaldo Cantani

झ acantani13@gmail.com

Department of Pediatrics, Division of Allergy and Immunology, Roma University La Sapienza, Italy.

Tel: 021-33-771002

Citation: Cantani A. In 250 Children, the Transmission of Allergy and Asthma is Chief Genetic, If these Children are Asthmatic. Insights Allergy Asthma Bronchitis. 2015, 1:1.

\section{Introduction}

Asthma may be a severe genetic ancestral affection whose mode of inheritance is full of mistery. Previously done researches suggest that a gene could be possibly involved in such a disease, but several different genetic models have been obtained. Twins 
coming from family studies may be useful to spot both genetic and environmental factors. The genetic basis of atopy have involved different researchers to find a conclusive genetic effect on total serum IgE levels in twins: the total serum IgE level discrepancy is signific- antly lower in pollen sensitive monozygotic (MZ) than in dizygotic (DZ) twins $(0,15$ vs 0,51$)$ [1] and the heritage index (the part variability ascribed to genetic factors) is assess- ed to be $59 \%$ in adults and $79 \%$ in children [2]. The genetic agreement between atopic dermatitis (AD) and asthma was greater in genetically identical $\mathrm{MZ}$ twins [3]. $\mathrm{MZ}$ twins have a larger concordance ratio for atopy $[1,4]$, while in DZ twins BHR (bronchial hyper-reactivity) and total and specific IgE [1] is preponderant. Therefore, the most reliable approach appears to be the actual accordance between $\mathrm{MZ}$ and $\mathrm{DZ}$ twins [5]. Twin studies have also revealed a positive evidence for environmental influences, where unshared environmental influences appeared to be important [6]. Most printed studies in this domain have ascertained that everywhere between $40 \%$ and $70 \%$ of asthma heredity is referable to hereditary factors [7].We stress that several studies on asthma genetics have been strengthen by diverse genome wide searches, that suceeded in establishing the linkage between asthma and genetic markers on 13 chromosome regions emboding chromosomes 5q31-33 (the gene cluster of good many interleukins), 6p21.3, 11q13 and $12 q 14.3-24.1[6,8-15] . I n$ this prospective study on 500 children we have appraised the asthma genetics, by estimating the $\mathrm{FH}$ of atopy of their respective family, including parents and brothers and/or sisters.

\section{Materials and Methods}

In order to investigate the genetic risk of a child with a family history (FH) of allergy, we have enlisted in this perspective study 250 children, 137 males and 113 females ethnically Italian, aged between 3.5 and 6.5 years (median age 4.4 years), In particular we have studied the personal and $\mathrm{FH}$ of both parents and children Study children We reckoned whether the babies were "at risk" of atopic disease because of a positive $\mathrm{FH}$ of atopy since one or both parents and/or their siblings suffered from asthma, or AD, or AR. The diagnosis of atopic diseases in the children was done according the following criteria: clinical history, physical examination and positive skin tests and/or RAST to the most common inhalant and/or food allergens. Two hundred and fifty healthy children, and their parents supplied during the same period from our outpatient clinic with no history of atopy of liken age, sex, and Italian origin were matched with the study group.

Informed consent was obtained from parents of each child.

\section{Skin prick test}

Appropriate emergency equipment and medications were available on site. Antihistamine drugs and topical steroids were stopped at least 2 weeks before the application of the SPTs. Skin testing was done at baseline by the prick method on the volar surface of the forearm by a trained in allergy doctor with the cooperation of a qualified nurse. The skin was marked with a ballpoint pen for the allergens to be tested. The babies were then tested with: histamine hydrochloride $(1 \mathrm{mg} / \mathrm{ml})$ as a positive control and isotonic saline as a negative control. We continued with a battery of food and inhalant allergens, including whole CM protein, casein, lactalbumin, egg, fish, wheat, soy, Dermatophagoides pteronyssinus, Alternaria alternata, Lolium perenne, Olea europea and Parietaria officinalis (SARM, Roma, Italy). The diagnostic extract of each individual allergen was placed on the volar surface of the forearm as drops through which the skin was superficially pricked with a straight pin for one second. A new pin was used for each SPT and then discarded, and the drop of the extract was then wiped off about one minute after the prick [16] SPTs were read 20 minutes after the test was finished and considered positive as follows:

+ when the wheal was the half of the histamine wheal;

++ when the wheal was equal to the histamine wheal;

+++ when the wheal was two-fold the histamine wheal;

++++ when the wheal was more than two-fold the histamine wheal [17].

We took for positive only children with a +++ or ++++ reaction, that is a wheal $\geq 3 \mathrm{~mm}$ with an area about $7 \mathrm{~mm} 2$ (cut-off) So we considered as positive only the children with a mean wheal diameter of $\geq 3 \mathrm{~mm}$ than the negative (saline) control. A positive (histamine) control was performed to ensure the absence of any antihistamine drug interference [18].

\section{Total IgE}

The determination of the total serum IgE level was done by paper radioimmunosorbent test (PRIST, Pharmacia Diagnostics $A B$, Sweden), and results were expressed in International Units per $\mathrm{ml}$.

Specific IgE antibodies and determination of specific IgE levels by radioallergosorbent test (Phadezym RAST, Pharmacia Diagnostics).

RAST results are expressed in "RAST Units» (PRU=Phadebas Rast Unit) as follows:

1st class $=$ IgE levels $<0,35 \mathrm{IU} / \mathrm{ml}$,

2nd class=lgE levels $>0,35 \mathrm{IU} / \mathrm{ml}$ and lesser than $0,7 \mathrm{I} \mathrm{U} / \mathrm{ml}$, 3rd class=lgE levels between $0,7 \mathrm{I} \mathrm{U} / \mathrm{ml}$ and $17 \mathrm{I} \mathrm{U} / \mathrm{ml}$, 4th class $=\mathrm{IgE}$ levels higher than $17 \mathrm{I} \mathrm{U/ml}$. Only RAST results $>0,35 \mathrm{IU} / \mathrm{ml}$ were considered as positive The diagnosis of AD was made according to Hanifin and Rajka criteria [19]. The severity score of $A D$ was evaluated according to the SCORAD index [20].

For the diagnosis of asthma, 3 episodes of wheezing without fever were required. Provocation tests with inhalant allergens were not feasible due to the young age of the children studied.

For the diagnosis of rhinitis, nasal discharge and/or blockage occurring continuously for at least 4 weeks plus the typical pale aspect of allergic mucosa on rhinoscopy, without any sign of infective rhinitis in other relatives was required.

The statistical calculations were performed using the $\mathrm{X} 2$ test.

\section{Results}

As demonstrated by FH, SPTs and RAST, 127 parents of the study children were affected with atopic disease (42.3\%), in particular 51 fathers and 76 mothers, in addition to 25 brothers and/or 
sisters. These parents all tested positive for inhalant allergens (both SPTs and RAST), with the exception of 3 mothers positive to $\mathrm{CM}$ allergens and two children with allergic migraine. We stress that $90.2 \%$ of fathers, $81.6 \%$ of mothers and $91.7 \%$ of brothers/sisters suffered from respiratory allergy. In detail, $41.2 \%$ of fathers, $40.8 \%$ of mothers and $72.2 \%$ of brothers/ sisters were asthmatic. In addition $49 \%, 40.8 \%$ and $19.4 \%$, respectively, were affected with AR. Moreover $9.8 \%$ of fathers and $6.6 \%$ of mothers had urticaria, $2.9 \%$ of mothers and $10.5 \%$ of brothers/sisters had AD, and $4 \%$ of mothers had CMA (Table 1).

Twenty-five children were allergic, with a high proportion of cases of AD (52\%), however the respiratory allergy affects $30.4 \%$ of these children (Table 2) who appear to have multiple sensitizations in $34.8 \%$ of cases (Table 3 ). Thirteen of these children had SPTs and RAST positive for food allergens (mostly $\mathrm{CM}$ and egg) and 10 for inhalant allergens.

In the control group 61 parents were allergic, and 40 were affected with respiratory allergy. In detail, $14,7 \%$ of fathers and mothers and $18,2 \%$ of brothers/sisters had asthma. 6,6\%, $13,1 \%$ and $4,9 \%$, respectively had $A R$ and $6,6 \%$ of fathers and mothers ed $3,3 \%$ of brothers/sisters allergic oculorhinitis Further, $6,6 \%$ of fathers $13,1 \%$ of mothers and $1,6 \%$ of brothers had urticaria, $11,5 \%$ of mothers and $1,6 \%$ of fathers and brothers $A D$, in addition to $3,3 \%$ of fathers, $11,5 \%$ of mothers and $8,2 \%$ of brothers/sisters with FA.

In the control group, 11 children were sensitized who in $15,5 \%$ of cases had respiratory allergy Study children vs controls $(p=0.0161)$.We have ascertained that a high number of parents of the study and control children were active smokers (Table 4). The statistical analysis revealed high statistically differences between fathers and mothers of the study group versus the parents of the controls, $p=0.0196$ and $p=0.0387$, respectively.

The statistical analysis has demonstrated highly significant differences between the two samples $(p=0,0001)$.

Table 1 Parents of children affected with atopic disease.

\begin{tabular}{|c|c|c|c|c|}
\hline Atopic disease & No. (\%) & F & M & (B/S) \\
\hline Asthma & $52(40.9)$ & 21 & 31 & 6 \\
\hline Allergic rhinitis & $57(44.8)$ & 25 & 32 & 4 \\
\hline Atopic dermatitis & $2(1.6)$ & 0 & 2 & 3 \\
\hline Urticaria & $10(7.8)$ & 5 & 5 & 3 \\
\hline Oculorhinitis & $3(2.5)$ & 1 & 2 & 1 \\
\hline Food allergy & $3(2.5)$ & 0 & 3 & 2 \\
\hline F=Fathers, M=mothers & 127 & 52 & 75 & 20 \\
\hline
\end{tabular}

Table 2 Children affected with atopic disease.

\begin{tabular}{|cc|}
\hline Atopic disease & No. (\%) \\
\hline Atopic dermatitis & $12(52.2)$ \\
\hline Asthma & $5(21.7)$ \\
\hline Urticaria & $4(17.3)$ \\
\hline Allergic migraine & $2(8.6)$ \\
\hline Oculorhinitis & $1(4.3)$ \\
\hline Allergic rhinitis & $1(4.3)$ \\
\hline
\end{tabular}

Table 3 Degree of sensitization of the 23 children.

\begin{tabular}{|c|c|}
\hline Degree of sensitization & No. (\%) \\
\hline Single sensitization & $15(65.2)$ \\
\hline Multiple sensitization & $8(34.8)$ \\
\hline
\end{tabular}

Table 4 Number of people smoking in the home of 125 children and 125 controls.

\begin{tabular}{|c|c|c|}
\hline Relative & $\begin{array}{c}\text { Children in study } \\
\text { Number \% }\end{array}$ & Controls Number \% \\
\hline Fathers & 12560,6 & 15351 \\
\hline Mothers & 9937.7 & 8929.7 \\
\hline Others & 155.2 & 258.3 \\
\hline $\begin{array}{c}\text { Fathers and Mothers } \\
\text { Fathers vs mothers }\end{array}$ & 9332.2 & 7324.3 \\
\hline p=0.0036 & & \\
\hline
\end{tabular}

\section{Discussion}

The results do not allow us to confirm that a significant proportions of respiratory allergy is transmitted by mothers. We underline that $42.3 \%$ of parents are atopic, with a FH positive for respiratory allergy in $82-92 \%$ of cases In the study sample 147 parents and brothers were affected with respiratory allergy $(45.94 \%)$ versus $10,3 \%$ of controls who in $65.5 \%$ of cases had respiratory allergy. Therefore, asthma is a genetic disease, at least in $42.3 \%$ of cases. Respiratory allergy can have an autosomal dominant mode of inheritance, but by considering the whole atopic whole, the transmission can be polygenic. The high impact of the genetic factors in these children is stressed by the high proportion (85\%) of asthmatic brothers/sisters. As regards the smoking parents it is very significant the number of couples smoking together. The low number of other relatives probably depends by the smaller apartments prevailing in Italy.

What our study evidently stresses is that a high number of parents, atopic parents, yet they themselves asthmatic, as we have ascertained, are smoking parents of asthmatic sons and daughters. Such data demonstrates in an unequivocal manner that cigarette smoke should be considered as a triggering factor of respiratory allergy. Therefore in babies at risk of atopy cigarette smoke should be regarded as an additional genetic factor, since asthma is more easily transmitted if an atopic parent smokes (even more if both parents smoke). However cigarette smoke is able to provoke asthma even in children of nonatopic parents, especially if the smokers are pregnant women: their children frequently suffer with Der p-induced asthma [17].

Allergic asthma and rhinitis, AD, urticaria and FA are genetic diseases of infants and children. Several investigators have provided evidence for a genetic localization for atopy. Babies of atopic parents are at high risk of developing atopic diseases, however the phenotypic expression of such disorders varies widely, being very mild in some infants and children, severe and frustrating in many, even lifethreatening in others, being also common, disabilitating, and chronic [21]. In particular we can now understand how strictly the genetic factors are linked with atopy: several cytokine genes are associated in the gene cluster of chromosome 5q23-q31, such as IL-3, IL-4, IL-5, IL9, IL-12b, IL-13, and GM-CSF, together with the genes for the 
ß2-adrenergic receptor [22]. It is likely that plural loci in the chromosome 5q31-q33 region are synergistically related to asthma susceptibility.

We have frequently spoken of respiratory allergy. However, a large number of cross-sectional studies have reported that asthma and AR commonly occur in children and adolescents [23-25]. Studies have demonstrated that AR occurs in $28-78 \%$ of older children and adolescents [23-25], versus approximately 5-20\% of the general population [16]. Conversely, asthma has also been shown to affect up to $38 \%$ of AR patients [23-25], a data significantly higher than the 3-5\% prevalence noted in the general population [16]. In an unpublished study on 411 children aged 7-13 years, asthma had an incidence of $31.5 \%$ and AR of $25.8 \%$. Asthma and AR can have an early onset. The asthma affair is a little more intricate: the onset within the first year is certain in 34,5\% [23$26]-56,2 \%[19,27]$ of babies, but a higher level $(82.4 \%)$ is evident between the 4 th and the 7 th year [19, 27-29]. That within the 8 th year the asthma onset is manifest in $90 \%$ of children [28] is confirmed by the $92 \%$ proportion reached in patients less than 20 years of age [31]. As regards AR, the onset may be in the first year in $35 \%$ of children and in $59 \%$ of those aged $2-5$ years [24], who in other studies are affected in $13-19 \%$ of cases $[23,30]$.

Once atopy develops, it is now possible to prevent the clinical manifestations in a great proportion of cases (secondary prevention) by the use of pharmacological agents such as cromones and ketotifen [32]. In addition as demonstrated by the ETAC study we can prevent the onset of respiratory allergy in $50 \%$ of babies with AD following an 18-month administration of cetirizine [33]. Since the commitment to the Th2 phenotype in atopics appears to occur at any time between the ages of 2 and 5 years [34], the net implication is that within the first years of life there is a window open for immunoprophylaxis [35].

\section{Conclusion}

In conclusion, we have proven that asthma is a genetic disorder and that the transmission of allergy and asthma is fully genetic in children, mainly if asthmatic. 


\section{References}

1 Bonini S, Rasi G, Celestino D (1983) Genetic aspects of allergic asthma-Twin studies. Proc XII Congr EAACl, Rome pp.109-122.

2 Bazaral M, Orgel HA, Hamburger RN (1974) Genetics of IgE and allergy: serum IgE levels in twins. J Allergy Clin Immunol 54: 288-304.

3 Edfords-Lubs MI (1971) Allergy in 7000 twin pairs. Acta Allergol 26: 249-285.

4 Hopkin JM (1995) The genetics of atopy. Pediatr Allergy Immunol 6 : 139-144.

5 Skadhauge LR, Christensen K, Kryvik KO (1999) Genetic and environmental influence on asthma: a population-based studt of 11,688 Danish twins. Eur Respir J 13: 8-14.

6 Los H, Koppelman GH, Postma DS (1999) The importance of genetic influences in asthma. Eur Respir J 14: 1210-1227.

7 Duffy DL, Martin NG, Battistutta D (1990) Genetic of asthma and hay fever in Australian twins. Am Rev Respir Dis 142: 1351-1358.

8 Daniels SE, Bhattacharrya S, James A (1996) A genome-wide search for quantitative trait loci underlying asthma. Nature 383: 247-250.

9 Xu J, Meyers DA, Ober C (2001) Genomewide screen and identification of gene-gene interactions for asthma susceptibility loci in three US populations: Collaborative study on the genetics of asthma. Am J Hum Genet 68: 1437-1448.

10 Nat Genet (1997) Collaborative study on the genetics of asthma (CSGA) A genome-wide search for asthma susceptibility loci in ethnically diverse populations. 15: 389-392.

11 Dizier M-H, Besse-Schmittler C, Guilloud-Bataille M (2000) Genome screen for asthma and related phenotypes in the French EGEA study. Am J Respir Crit Care Med 162: 1812-181.

12 Ober C, Tsalenko A, ParryB, Cox NJ (2000) A second-generation genome-wide screen for asthma susceptibility alleles in a founder population. Am J Hum Genet 67: 1154-1162.

13 Wjst M, Fischer G, Immervoll T (1999) A genome-wide search for linkage to asthma. German Asthma Genetics Group. Genomics 58: 1-18.

14 Koppelman GH, Stine OC, Xu J (2002) Genome-wide screen for atopy susceptibility genesa in Dutch families with asthma. J Allergy Clin Immunol 109: 498-506.

15 Renz H, von Mutius E, Illi S, Wolkers F, Hirsch T et al. (2002) Th1/Th2 immune response profiles differ between atopic children in eastern and western Germany. J Allergy Clin Immunol 109: 338-342.

16 Settipane RJ, Hagy GW, Settipane GA (1994) Long term risk factors for developing asthma and allergic rhinitis: a 23-year follow-up of college students. Allergy Proc 15: 21-25.

17 Cantani A, Jovanidis N, Gagliesi D (1998) fumo materno durante e dopo la gravidanza associato allo sviluppo di asma da Der $\mathrm{p}$ nel bambino. Aggiorn Pediatr 1: 5-10.
18 Blair H.(1974) The incidence of asthma, hay fever and infantile eczema in an East London group practice of 9145 patients. Clin Allergy 4: 389-399.

19 Koivikko (1974) A. Childhood asthma in Finland. Acta Allergol 29: 30-72.

20 Croner S, Kjellman N-IM (1992) Natural history of bronchial asthma in childhood. A prospective study from birth up to 12-14 years of age. Allergy 47: 150-157

21 Cantani A (1999) The growing genetic links and the early onset of atopic diseases in children stress the unique role of the atopic march: a meta-analysis. J Invest Allergol Clin Immunol 9: 314-320

22 Anderson GG, Morrison JFJ (1998) Molecular biology and genetics of allergy and asthma. Arch Dis Child 78: 488-496

23 Blair H (1977) Natural history of childhood asthma. Arch Dis Child 52: 613-619

24 Smith JM (1983) Epidemiology and natural history of asthma, allergic rhinitis and atopic dermatitis. In Middleton E Jr, Reed CE, Ellis EE ed. Allergy: Principles and Practice (2nd ed) St Louis: CV Mosby pp: 771-803

25 Pedersen PA, Weeke ER (1983) Asthma and allergic rhinitis in the same patients. Allergy 38: $25-29$

26 Businco L, Falconieri P, Zannino L, Cantani A (1993) Presentazione dei risultati di uno studio policentrico epidemiologico delle malattie allergiche in età evolutiva in Italia. Notiz Allergol 12: 275-278

27 Gergen PJ, Turkeltaub PC, Kramer RA (1992) Age of onset in childhood asthma: data from a national cohort. Ann Allergy 68: 507-514

28 Bergmann RL, Bergmann KE, Lau-Schadensdorf S (1994) Atopic disease in infancy. The German multicenter atopy study (MAS-90). Pediatr Allergy Immunol 5:19-25

29 Linna O, Kokkonen J, Lahtela P, Tammela O (1992) A 10-year prognosis for generalized infantile eczema. Acta Pædiatr 81: 1013-1016

30 Rich SS, Roitman-Johnson B, Greenberg B, Roberts S, Blumenthal MN (1992) Genetic analysis of atopy in three large kindreds: no evidence of linkage to D11S97. Clin Exp Allergy 22: 1070-1076

31 Jenkins MA, Hopper JL, Bowes G, Carlin JB, Flander LB et al. (1994) Factors in childhood as predictors of asthma in adult life. BMJ 309: 90-93

32 Cantani A (2008) Pediatric allegy, asthma and immunology. Springer, Heidelberg

33 Warner JO (1997) Early treatment of the atopic child. Pediatr Allergy Immunol 8:46-48

34 Yabuhara A, Macaubas C, Prescott SL, Venaille TJ, Holt BJ et al. (1997) Th2-polarized immunological memory to inhalant allergens in atopics is established during infancy and early childhood. Clin Exp Allergy 27: 1261-1269

35 Holt PG (1994) A potential vaccine strategy for asthma and allied atopic diseases during early childhood. Lancet 344: 456-458 